\title{
Zastosowanie półautomatycznego algorytmu doboru optymalnej liczby i położenia odwiertów wydobywczych
}

\begin{abstract}
Artykuł poświęcono zastosowaniu tzw. algorytmu nietoperza do rozwiązania problemu określenia optymalnej liczby i położenia odwiertów wydobywczych. W procesie optymalizacji jako funkcję celu wykorzystano bieżącą wartość netto (ang. net present value - NPV). Testy zbudowanego algorytmu przeprowadzono na przykładzie modelu symulacyjnego złoża PUNQ-S3, dostępnego na zasadach open source. Zastosowany algorytm został wyposażony w dodatkowe mechanizmy zwiększające jego efektywność: mechanizm próbkowania sześcianu łacińskiego (ang. Latin hypercube sampling - LHS) oraz mechanizm eliminowania położeń odwiertów poza modelem. Przeprowadzone testy wskazują na bardzo dobrą zbieżność zbudowanego algorytmu w procesie optymalizacji.
\end{abstract}

Słowa kluczowe: optymalizacja, algorytm nietoperza, położenie odwiertów, NPV, eksploatacja, algorytmy rojowe.

\section{Semi-Automatic Algorithm for Optimal Production Well Placement}

The article is devoted to the application of the so-called bat algorithm to solve the problem of determining the optimum number and location of production wells. This algorithm was proposed by Yang in 2010, and since then has been successfully used in solving both theoretical and practical optimization problems. The method belongs to a group of swarm optimization methods and in searching for the best solution, the algorithm uses a mechanism of echolocation, similar to the one used by a herd of bats. The current net present value (NPV) was used as a target function in the optimization process. The algorithm was tested on the example of the simulation model of the PUNQ-S3 reservoir available on an OpenSource basis. The applied algorithm was equipped with additional mechanisms increasing its effectiveness: Latin Hypercube Sampling (LHS) algorithm and the mechanism eliminating the locations of wells outside the operational area of the model. The first of the applied improvements ensures a better starting point for the proper optimization process, which significantly improves the convergence of the whole algorithm. The latter mechanism solves a problem specific to the issue in question.

Key words: optimization, bat algorithm, location of wells, NPV, exploitation, swarm algorithms.

\section{Wstęp}

Efektywność eksploatacji złoża węglowodorowego zależy istotnie od wielu czynników, takich jak: liczba i rodzaj odwiertów, ich lokalizacja, limity eksploatacyjne oraz parametry ekonomiczne. Złożony problem optymalnej eksploatacji złoża jest dodatkowo komplikowany poprzez nieliniowy wpływ nieznanych lub słabo rozpoznanych wielkości charakteryzujących złoże. Istotnym problemem wydaje się zatem zautomatyzowanie procesu określania parametrów mających największy wpływ na efektywność eksploatacji złoża.

Przedstawiony problem jest tematem wielu opracowań i publikacji. W szczególności w literaturze spotyka się różne podejścia do rozwiązania zagadnienia optymalnego rozmieszczenia odwiertów wydobywczych i optymalizacji wydobycia, takie jak:
- sztuczne sieci neuronowe w połączeniu z algorytmem genetycznym [25],

- hybrydowe algorytmy genetyczne [9],

- metody półanalityczne uwzględniające niejednorodność i anizotropię złoża [10],

- gradientowe metody optymalizacji [26],

- optymalizacja rojem cząstek [12, 19],

- optymalizacja retrospektywna i próbkowanie klastrowe [22],

- strategie ewolucyjne [4].

Wśród strategii ewolucyjnych najczęściej wykorzystywane są algorytmy genetyczne $[1,5,7,8,11,14,18,20]$ oraz optymalizacja rojem cząstek [12, 19, 21]. Jedną z najbardziej efektywnych metaheurystyk należących do grupy algorytmów rojowych jest tzw. algorytm nietoperza (ang. bat algorithm) 
zaproponowany przez Yanga [23, 24]). Znalazł on zastosowanie przy rozwiązywaniu szeregu problemów z dziedziny optymalizacji [2, 13, 15-16].

Tematem prezentowanej pracy jest próba wykorzystania automatycznego algorytmu doboru liczby i lokalizacji odwiertów wydobywczych opartego na algorytmie nietoperza w celu optymalizacji wydobycia ropy naftowej w zadanym czasie eksploatacji. Jako miarę efektywności eksploatacji przyjęto wartość NPV (wartość bieżąca netto, ang. net present value) opartą na analizie zdyskontowanych przepływów pieniężnych przy zadanej stopie zwrotu.
Zakres pracy obejmuje:

- wybór metody rozwiązania dla sformułowanego problemu,

- zbudowanie efektywnego algorytmu realizującego proces optymalizacji,

- implementację numeryczną stworzonego algorytmu,

- przeprowadzenie symulacji działania algorytmu w celu znalezienia optymalnego położenia i liczby odwiertów produkcyjnych dla złoża testowego.

Tak sformułowany problem jest przykładem optymalizacji globalnej w przestrzeni dozwolonych położeń odwiertów produkcyjnych.

\section{Sformułowanie problemu}

Cel pracy zrealizowano na przykładzie następującego problemu optymalizacyjnego: Poszukujemy takich lokalizacji oraz wydajności odwiertów wydobywczych, aby wartość bieżaca netto (NPV) byta jak największa dla zmiennej liczby odwiertów $i$ dla zadanego czasu eksploatacji.

Optymalizację prowadzono dla trójfazowego (ropa, woda, gaz) modelu złoża PUNQ-S3 [3, 6]. Model symulacyjny złoża PUNQ-S3 został udostępniony przez firmę Elf dla celów testowych i jest dostępny na zasadach open source. Składa się on z 2660 bloków (siatka bloków $19 \times 28 \times 5$ ), z czego 1761 bloków jest aktywnych. Opisywany niejednorodny model symulacyjny charakteryzuje się następującymi własnościami petrofizycznymi: (1) średnia porowatość: 14,3\%, (2) średnia przepuszczalność pozioma: $278,8 \mathrm{mD}$, (3) średnia przepuszczalność pionowa: 130,6 mD. W modelu uwzględniono uskok oraz dwa aktywne akifery typu Cartera-Tracy'ego. Proces optymalizacji prowadzono dla sumarycznego wydobycia ropy naftowej przy eksploatacji złoża zmienną liczbą odwiertów eksploatacyjnych. W aplikacji wykorzystano symulator złożowy Black Oil Eclipse 100 firmy Schlumberger. Na rysunku 1 przedstawiono widok 3D wykorzystane- go w pracy modelu złożowego dla rzeczywistego rozmieszczenia odwiertów.

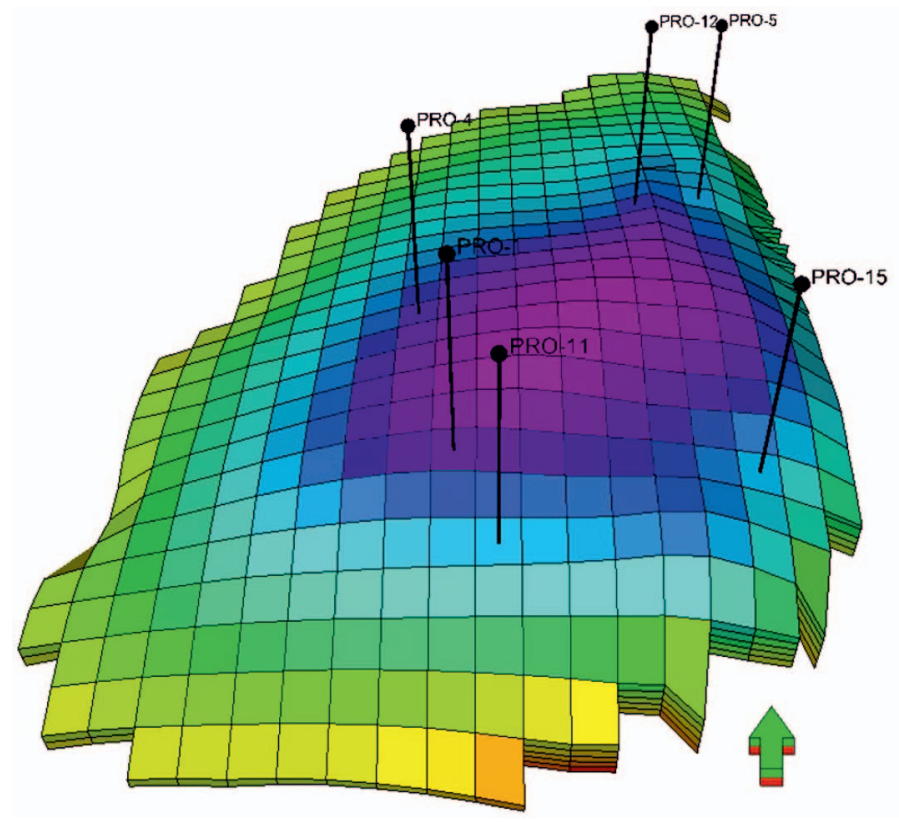

Rys. 1. Złoże PUNQ-S3. Widok 3D

\section{Schemat działania algorytmu optymalizacyjnego}

W celu rozwiązania postawionego problemu optymalizacyjnego zaimplementowano program numeryczny realizujący algorytm nietoperza (ang. bat algorithm).

Poniżej przedstawiono szczegóły przyjętego rozwiązania:

1. Wczytanie parametrów pracy programu (parametry sterujące, parametry metody optymalizacyjnej, optymalizacyjne parametry modelu, ich zakresy zmienności oraz definicje wielkości kontrolnych).

2. Inicjalizacja parametrów sterujących algorytmu:

$N$ - liczebność roju rozwiązań,

$f_{\min }-$ minimalna wartość częstotliwości,

$f_{\max }-$ maksymalna wartość częstotliwości, $r_{\text {min }}$ - minimalna wartość częstości emisji impulsów,

$r_{\max }$ - maksymalna wartość częstości emisji impulsów,

$L_{i}(0)$ - głośność początkowa dla każdego elementu roju rozwiązań,

$\alpha$ - współczynnik redukujący głośność,

$\beta$ - współczynnik zwiększający częstość emisji impulsów.

3. Wylosowanie roju rozwiązań (grupy modeli) dla różnych kombinacji wartości parametrów optymalizacyjnych modelu. Wartości parametrów są wyznaczane metodą próbkowania hipersześcianu łacińskiego w zadanych zakresach zmienności. Przyjęto zasadę, że na tym etapie 
algorytm operuje na podwojonej liczebności roju rozwiązań. Jeżeli np. przyjmiemy, że podstawowy rój rozwiązań liczy $N=10$ osobników, to na tym etapie algorytm przetwarza $2 N=20$ rozwiązań.

4. Wyznaczenie wartości funkcji celu dla każdego z modeli roju. Zastosowano funkcję celu w postaci NPV:

$$
N P V=-\left(\sum_{i=1}^{T} \frac{Q_{o i} P_{o}-Q_{w i} P_{w}-O P E X}{(1+D)^{i}}-C A P E X\right)
$$

gdzie:

$T$ - liczba lat eksploatacji,

$Q_{o i}$ - sumaryczne wydobycie ropy w $i$-tym roku eksploatacji,

$P_{o}$ - cena $1 \mathrm{~m}^{3}$ ropy naftowej,

$Q_{w i}$ - sumaryczne wydobycie wody w $i$-tym roku eksploatacji,

$P_{w}$ - koszt utylizacji $1 \mathrm{~m}^{3}$ wody złożowej,

$O P E X, C A P E X$ - odpowiednio nakłady operacyjne i inwestycyjne,

$D$ - stopa dyskontowa.

5. Wybór $N$ najlepszych (o najniższej wartości NPV) rozwiązań, stanowiących początkowy rój rozwiązań dla głównej pętli optymalizacyjnej.

6. Inicjalizacja głównej pętli optymalizacyjnej.

7. Częstotliwości, prędkości oraz rozwiązania są modyfikowane zgodnie z poniższymi formułami optymalizacji globalnej:

$$
\begin{aligned}
& f_{i}=f_{\text {min }}+\left(f_{\text {min }}-f_{\text {max }}\right) \cdot \operatorname{rnd}(0,1) \\
& v_{i}^{t}=v_{i}^{t-1}+\left(x_{i}^{t-1}-x_{*}\right) f_{i} \\
& x_{i}^{t}=x_{i}^{t-1}+v_{i}^{t}
\end{aligned}
$$

gdzie:

$f_{\min }, f_{\max }$ - odpowiednio minimalna i maksymalna wartość częstotliwości,

rnd $(0,1)$ - liczba losowa z zakresu $(0,1)$,

$v_{i}^{t}$ - prędkość rozwiązania dla czasu $t$,

$x_{i}^{t}-$ rozwiązanie dla czasu $t$,

$x_{*}$ - najlepsze rozwiązanie na danym etapie optymalizacji.

8. Uruchomienie procedury optymalizacji lokalnej.

Jeżeli zachodzi warunek:

$$
\operatorname{rnd}(0,1)<r(i)
$$

rozwiązanie otrzymane w punkcie (7) jest wyznaczane zgodnie z następującą formułą:

$$
x_{i}^{t}=x_{*}+\operatorname{rnd}(- \text { eps, eps }) \cdot L_{\text {mean }}
$$

gdzie:

eps - zadany arbitralnie promień otoczenia,

$L_{\text {mean }}-$ średnia głośność.
9. Wyznaczenie wartości funkcji celu dla $i$-tego rozwiązania, $f_{i}^{t}$.

10. Aktualizacja $i$-tego rozwiązania.

Jeżeli zachodzą warunki:

$$
\operatorname{rnd}(0,1)<L(i) \text { i } f_{i}^{t}<f_{i}^{t-1}
$$

następuje aktualizacja rozwiązania.

11. Aktualizacja najlepszego rozwiązania.

Jeżeli zachodzi warunek:

$$
f_{i}^{t}<f_{*}
$$

aktualizowane są wartości $L(i), r(i), f_{*}, x_{*}$ zgodnie z poniższymi formułami:

$$
\begin{aligned}
& L(i)=\alpha L(i) \\
& r(i)=r_{\text {min }}+\left(r_{\text {min }}-r_{\text {max }}\right) \cdot\left(1-e^{-\beta \cdot t}\right) \\
& f_{*}=f_{i}^{t} \\
& x_{*}=x_{i}^{t}
\end{aligned}
$$

12. Punkty 7-11 są wykonywane dla każdego elementu roju rozwiązań.

13. Sprawdzenie warunku zakończenia optymalizacji. Jeżeli warunek zakończenia optymalizacji nie został spełniony - powrót do punktu 6.

Przedstawiona procedura jest wykonywana do momentu osiągnięcia warunku zakończenia obliczeń, np. osiągnięcia określonej liczby wykonanych symulacji (wywołań funkcji celu).

Algorytm został zbudowany w taki sposób, aby wyeliminować konieczność udziału użytkownika w czasie procesu optymalizacji. W związku z tym program został wyposażony w moduły analizy, kopiowania, przenoszenia i modyfikowania plików wsadowych zawierających dane oraz wyniki symulacji. Po wykonaniu niezbędnych operacji program uruchamia symulator złożowy, a po zakończeniu symulacji analizuje uzyskane wyniki.

\section{Reprezentacja zmiennych optymalizacyjnych $w$ programie numerycznym}

Zmiennymi optymalizacyjnymi dla przedstawionego problemu są: liczba odwiertów, położenie każdego z odwiertów, udostępnienie odwiertu oraz zadana wydajność wydobycia. Dla każdego odwiertu mamy więc 5 zmiennych optymalizacyjnych:

- położenie definiowane przez numery bloków modelu: X, Y (liczby całkowite),

- udostępnienie odwiertu definiowane przez numery warstw modelu: $Z_{1}$ i $Z_{2}$ (liczby całkowite),

- wydajność wydobycia.

Zgodnie z przyjętymi powyżej założeniami dla 6 odwiertów eksploatacyjnych otrzymujemy 30 zmiennych optymalizacyjnych, z których 24 są kodowane liczbami całkowitymi, a 6 liczbami rzeczywistymi. Dla każdej ze zmiennych określono jej 
minimalną i maksymalną wartość dozwoloną. Współrzędne odwiertów oraz udostępnienie są ograniczone przez rozmiary modelu, natomiast początkowa wydajność wydobycia należy do przedziału $50-500 \mathrm{~m}^{3} /$ dobę.

\section{Próbkowanie sześcianu tacińskiego}

W procesie inicjalizacji roju rozwiązań (pkt 3 algorytmu) zastosowano metodę próbkowania sześcianu łacińskiego, należącą do grupy technik projektowania eksperymentu i będącą jedną z najbardziej efektywnych metod generowania próbek losowych na podstawie funkcji gęstości prawdopodobieństwa. Idea metody sprowadza się do podziału przestrzeni losowej na rozdzielne podobszary poprzez podział zakresów zmienności każdej składowej w $\mathrm{N}$-wymiarowej przestrzeni zmiennych na określoną liczbę podprzedziałów. Następnie generowana jest określona liczba próbek w taki sposób, że z każdego podobszaru otrzymujemy jedną próbkę zbudowaną na zasadzie kombinatoryki pomiędzy wszystkimi wymiarami w przestrzeni rozwiązań. Na rysunku 2 przedstawiono zasadę generowania próbek dla metody próbkowania hipersześcianu łacińskiego w przypadku dwuwymiarowym. Próbki w danym podobszarze przestrzeni losowej są wybierane za pomocą odwrotności dystrybuanty rozkładu prawdopodobieństwa pojedynczej skła-

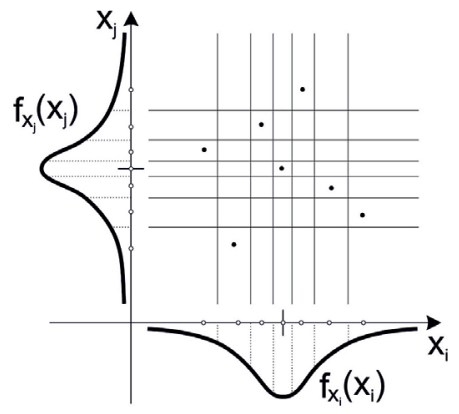

\author{
Rys. 2. Zasada \\ generowania próbek \\ metodą próbkowania \\ hipersześcianu łacińskiego \\ w przypadku przestrzeni \\ dwuwymiarowej
}

dowej wektora zmiennej losowej, przy czym dla każdej składowej można zastosować inny rozkład prawdopodobieństwa.

\section{Inicjalizacja populacji poczatkowej}

Inicjalizacja algorytmu wymaga wygenerowania populacji początkowej dla roju rozwiązań. W zbudowanym algorytmie zastosowano technikę polegającą na wygenerowaniu dwukrotnie większej liczby rozwiązań niż założona liczebność roju. Po wyznaczeniu dopasowania dla elementów powiększonego roju rozwiązań wybierano $N=10$ najlepszych rozwiązań stanowiących populację początkową. Mechanizm ten realizuje wstępne przeszukiwanie przestrzeni rozwiązań i w istotny sposób poprawia zbieżność algorytmu optymalizacyjnego poprzez poprawienie warunków początkowych.

\section{Problem bloków nieaktywnych}

W algorytmie zaimplementowano mechanizm eliminujący takie położenia odwiertów, dla których odwiert jest udostępniony w nieaktywnych blokach modelu. Mechanizm polega na stopniowym przemieszczaniu odwiertów udostępnionych w blokach nieaktywnych w kierunku środka modelu do momentu osiągnięcia pełnego udostępnienia w 5 warstwach modelu.

\section{Optymalizacja liczby i położenia odwiertów wydobywczych}

\section{Dobór parametrów sterujących algorytmu}

Jakkolwiek algorytm nietoperza charakteryzuje się dobrą zbieżnością, to jednak w porównaniu z innymi heurystykami optymalizacyjnymi wymaga określenia stosunkowo dużej liczby parametrów sterujących. W pracy przyjęto przedstawione poniżej wartości:

$N=10-$ liczebność roju rozwiązań,

$f_{\text {min }}=0,0-$ minimalna wartość częstotliwości,

$f_{\max }=1,0$ - maksymalna wartość częstotliwości,

$r_{\text {min }}=0,0$ - minimalna wartość częstości emisji impulsów,

$r_{\max }=0,9-$ maksymalna wartość częstości emisji impulsów,

$L_{i}(0)=0,9$ - głośność początkowa,

$\alpha=0,95$ - czynnik redukujący głośność,

$\beta=0,9$ - czynnik redukujący częstości emisji impulsów.

Zbudowany algorytm ewolucyjny zaimplementowano w kompilatorze Parallel Studio XE 2011 firmy Intel. Przy wyznaczaniu wartości funkcji przystosowania użyto symulatora złożowego ECLIPSE 100 firmy Schlumberger.
Dla każdego z przedstawionych poniżej przykładów optymalizacji przyjęto:

- maksymalną liczbę symulacji: 150 ,

- liczbę osobników w populacji początkowej: 20,

- liczbę osobników w kolejnych populacjach: 10.

Przyjęto ponadto:

$P_{o}=629 \$$ (cena $1 \mathrm{~m}^{3}$ ropy naftowej),

$P_{w}=31 \$$ (koszt utylizacji $1 \mathrm{~m}^{3}$ wody złożowej),

$O P E X=833,3$ tys. $\$$ (roczny nakład operacyjny/odwiert),

$C A P E X=11,7 \mathrm{mln} \$$ (nakład inwestycyjny/odwiert),

$D=0,1$ (stopa dyskontowa).

\section{Dobór optymalnej liczby odwiertów wydobywczych}

W celu wyznaczenia optymalnej liczby odwiertów eksploatacyjnych wykonywano dwudziestoletnie prognozy wydobycia, maksymalizując w procesie optymalizacji wartość NPV. Prognozy były prowadzone dla zmiennej liczby odwiertów, 5-9, po 10 powtórzeń procesu optymalizacji dla każdej 
Tablica 1. Sumaryczne wydobycie ropy, wody złożowej oraz wartość bieżąca netto dla różnych liczb odwiertów wydobywczych

\begin{tabular}{|c|c|c|c|c|}
\hline $\begin{array}{c}\text { Liczba } \\
\text { odwiertów }\end{array}$ & $\begin{array}{l}\text { Sumaryczne wydobycie } \\
\text { ropy, FOPT }\end{array}$ & $\begin{array}{l}\text { Sumaryczne wydobycie } \\
\text { wody złożowej, FWPT }\end{array}$ & $\begin{array}{l}\text { Wartość bieżąca } \\
\text { netto, NPV }\end{array}$ & Zmiana \\
\hline produkcyjnych & {$\left[\mathrm{mln} \mathrm{m}^{3}\right]$} & {$\left[\mathrm{mln} \mathrm{m}^{3}\right]$} & [mld \$] & [mld \$] \\
\hline 5 & 4,34 & 1,23 & 1,27 & - \\
\hline 6 & 4,98 & 2,08 & 1,62 & 0,35 \\
\hline 7 & 5,20 & 2,61 & 1,70 & 0,08 \\
\hline 8 & 5,59 & 3,67 & 1,83 & 0,13 \\
\hline 9 & 5,23 & 2,87 & 1,69 & $-0,14$ \\
\hline
\end{tabular}

liczby odwiertów. W prognozach przyjęto sterowanie wydajnością wydobycia odwiertów z limitem wykładnika gazowego $G O R_{\max }=250$ oraz minimalnym ciśnieniem na spodzie odwiertu $B H P_{\min }=150$ barów. Sumaryczne wydobycie ropy i wody złożowej oraz wartość NPV dla przeprowadzonych testów przedstawiono $\mathrm{w}$ tablicy 1 .

W wyniku przeprowadzonych testów stwierdzono, że dla przyjętych limitów eksploatacyjnych maksymalny zysk dla dwudziestoletniej eksploatacji uzyskujemy przy eksploatacji złoża 8 odwiertami. Zmienność sumarycznego wydobycia ropy i wody złożowej oraz wartości bieżącej netto - NPV w funkcji liczby odwiertów przedstawiono odpowiednio na rysunkach 3 i 4 . Lokalizacja odwiertów eksploatacyjnych dla wariantu optymalnego została przedstawiona na rysunku 5 . Rysunek 6 prezentuje sumaryczne wydobycie ropy - FOPT, wydajność wydobycia ropy - FOPR i sumaryczne wydobycie wody złożowej - FWPT, w wariancie optymalnym, natomiast na rysunkach 7 i 8 przedstawiono wydajności wydobycia i ciśnienia na spodzie odwiertów w tym wariancie. Rysunki 9-12 prezentują lokalizację odwiertów w pozostałych wariantach.

W każdym z analizowanych wariantów (liczba odwiertów wydobywczych 5-9, rysunki 5, 9-12) algorytm rozmieszczał odwierty w pobliżu kontaktu ropa-gaz, eliminu-

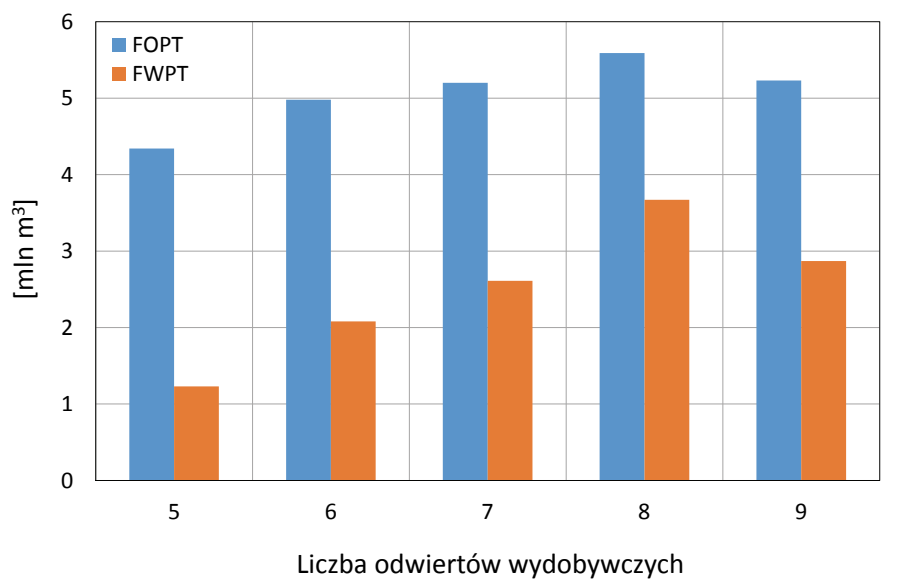

Rys. 3. Sumaryczne wydobycie ropy - FOPT i wody złożowej - FWPT w funkcji liczby odwiertów wydobywczych jąc lokalizacje mające negatywny wpływ na wydobycie, tzn. kontakt ropa-woda oraz krawędź modelu. W każdym z wariantów odwierty bardzo szybko osiągają limit ciśnienia dennego, przy czym w wariancie optymalnym następuje to maksymalnie do 4 . roku eksploatacji. Wydajności początkowe w tym wariancie wynoszą dla poszczególnych odwiertów: W1 (420 m 3 dobę), W2 $\left(360 \mathrm{~m}^{3} /\right.$ dobę $)$, W3 (490 $\mathrm{m}^{3} /$ dobę), W4 (130 $\mathrm{m}^{3} /$ dobę), W5 (310 $\mathrm{m}^{3} /$ dobę), W6

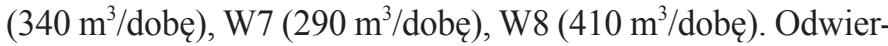
ty stosunkowo szybko redukują wydajności ze względu na limit ciśnienia dennego i przez większą część czasu eksploatacji wydobywają z wydajnościami od $50 \mathrm{~m}^{3} /$ dobę do $150 \mathrm{~m}^{3} /$ dobę.

Jakkolwiek optymalnym rozwiązaniem ze względu na przyjęte kryterium okazał się wariant z 8 odwiertami wydobywczymi (zdyskontowany zysk netto po 20 latach $-1,83$ mld \$), to jednak w tym wariancie odwiert W2 (rysunki 5 i 7) bardzo szybko redukuje wydajność wydobycia praktycznie do zera, co jest spowodowane jego lokalizacją pomiędzy dwoma odwiertami: W1 i W5. Najwyższą średnią wydajnością w wariancie optymalnym charakteryzuje się odwiert W3, położony w pewnej odległości od pozostałych odwiertów. Biorąc pod uwagę niskie wydajności odwiertu W2 oraz pamiętając o tym, że przedstawione wyniki mają charakter statystyczny (przy każdym uruchomieniu algorytmu optymalizacyjnego otrzymujemy „trochę” inne wyniki), można podejrzewać, że możliwe jest uzyskanie lepszego rozwiązania dla mniejszej liczby odwiertów. Jeżeli zauważymy ponadto, że maksymalny przyrost zysku (rysunek 4) otrzymujemy, zwiększając liczbę odwiertów z 5 do 6 , można przypuszczać, że rzeczywista optymalna liczba odwiertów to 6, 7 lub 8. Złoże PUNQ-S3 jest w rzeczywistości eksploatowane 6 odwiertami wydobywczymi.

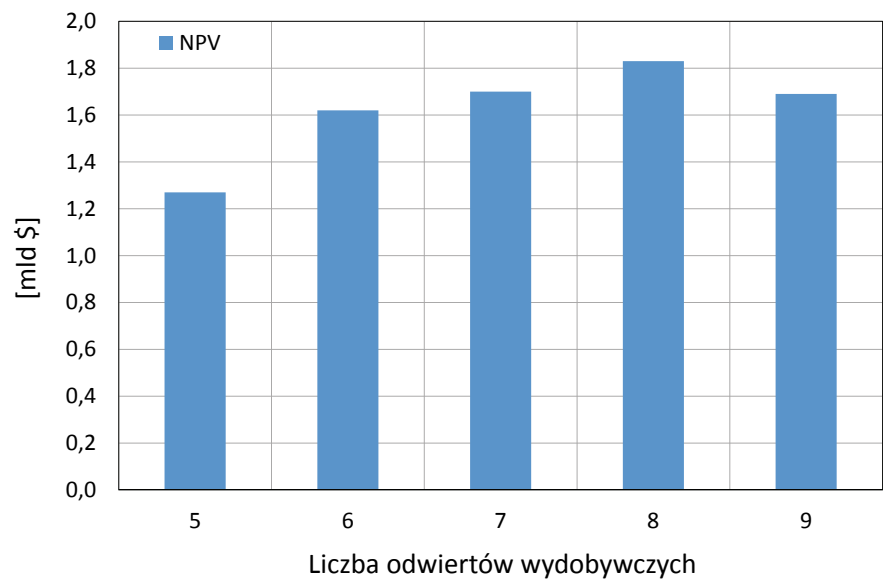

Rys. 4. Wartość bieżąca netto - NPV w funkcji liczby odwiertów eksploatacyjnych 


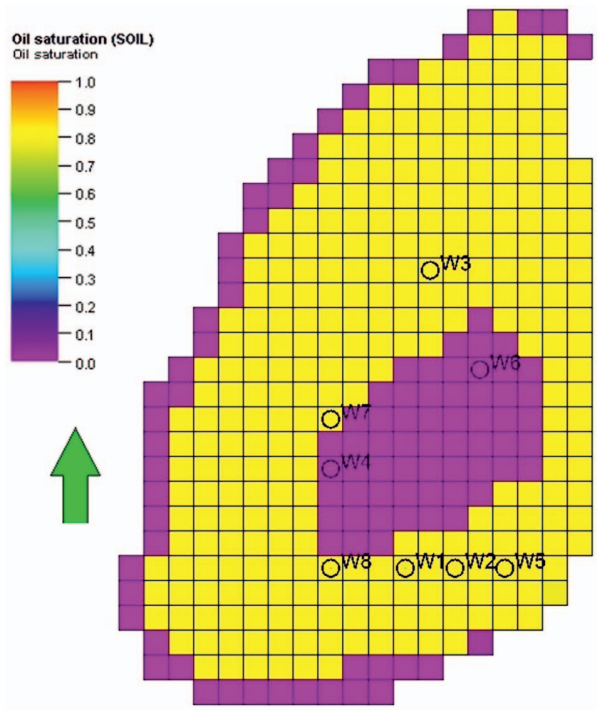

Rys. 5. Lokalizacja odwiertów w wariancie optymalnym

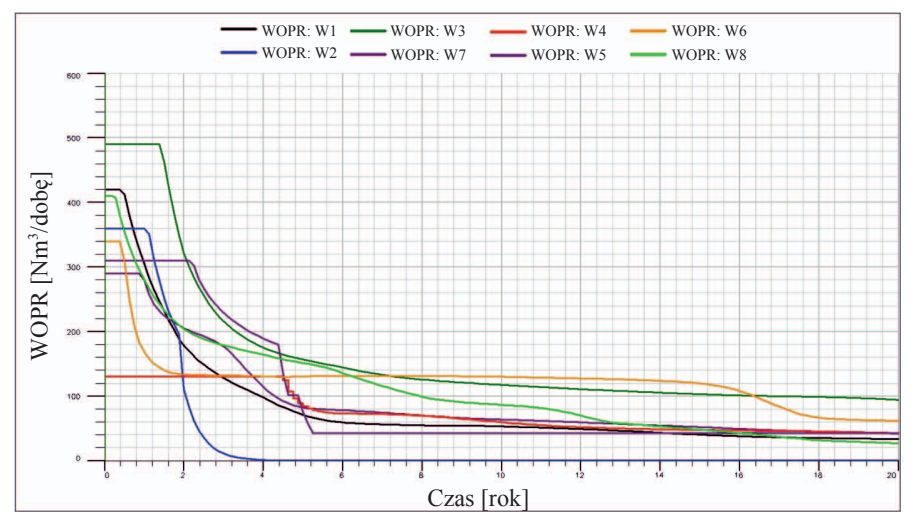

Rys. 7. Wydajności wydobycia - WOPR odwiertów $\mathrm{w}$ wariancie optymalnym

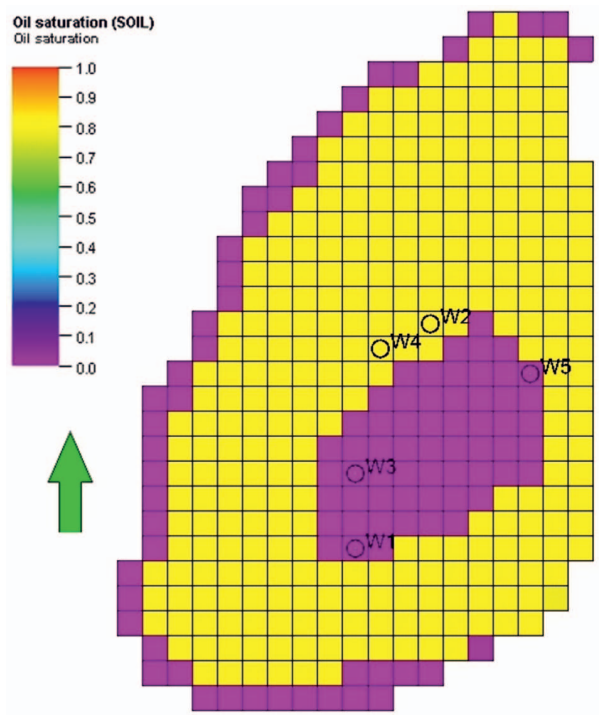

Rys. 9. Optymalna lokalizacja odwiertów 5 odwiertów wydobywczych

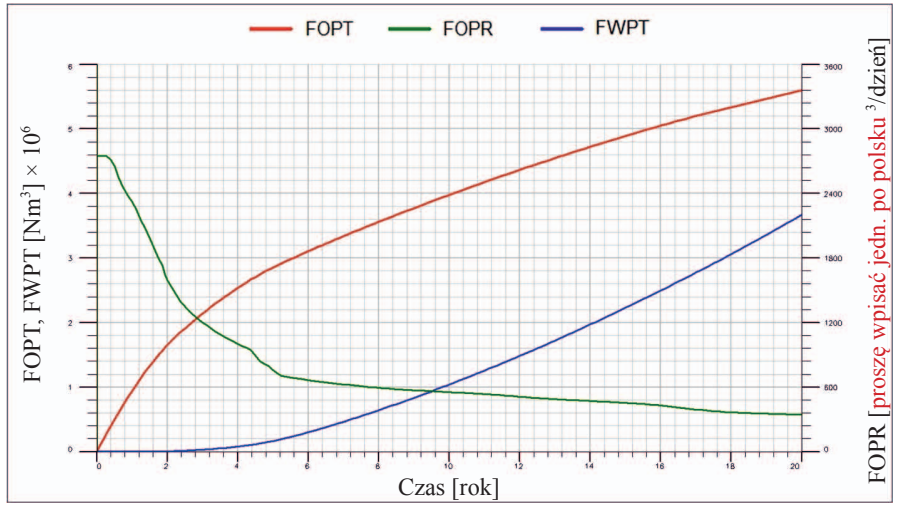

Rys. 6. Sumaryczne wydobycie ropy - FOPT i wody złożowej - FWPT oraz wydajność wydobycia ropy - FOPR $\mathrm{W}$ wariancie optymalnynym

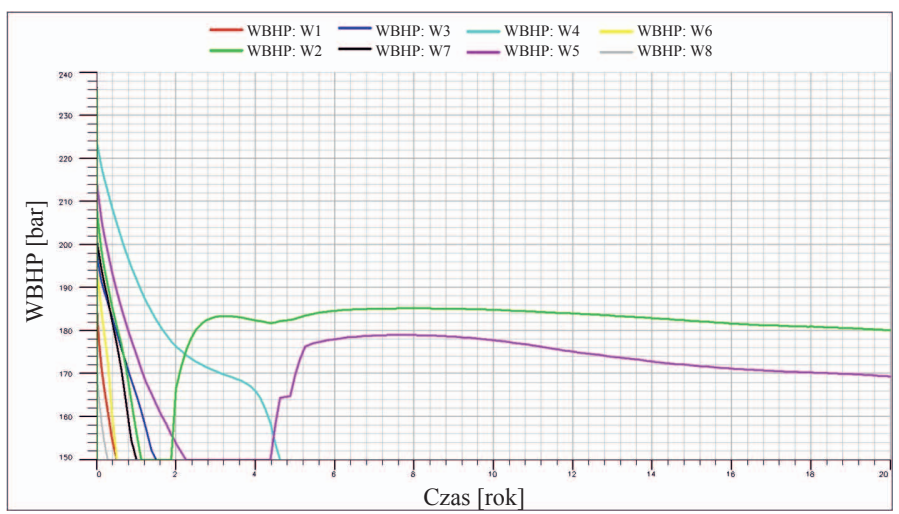

Rys. 8. Ciśnienia na spodzie odwiertów - WBHP $\mathrm{w}$ wariancie optymalnym

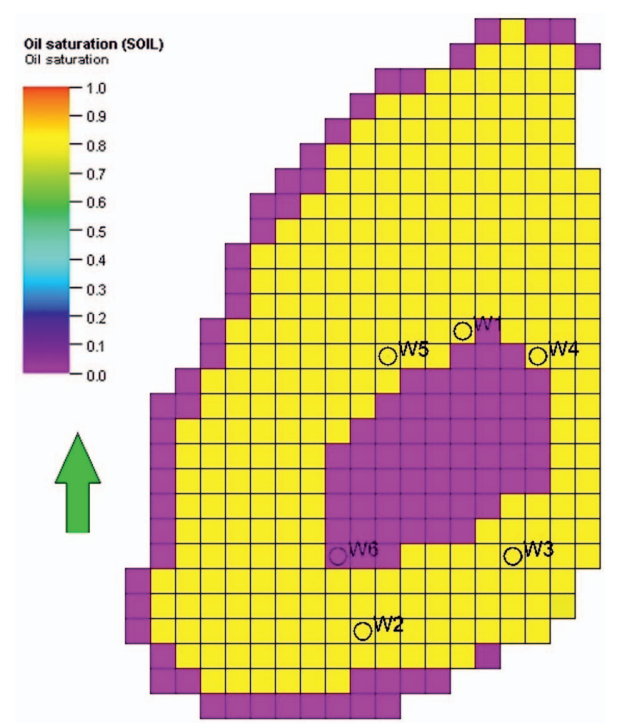

Rys. 10. Optymalna lokalizacja odwiertów 6 odwiertów wydobywczych 


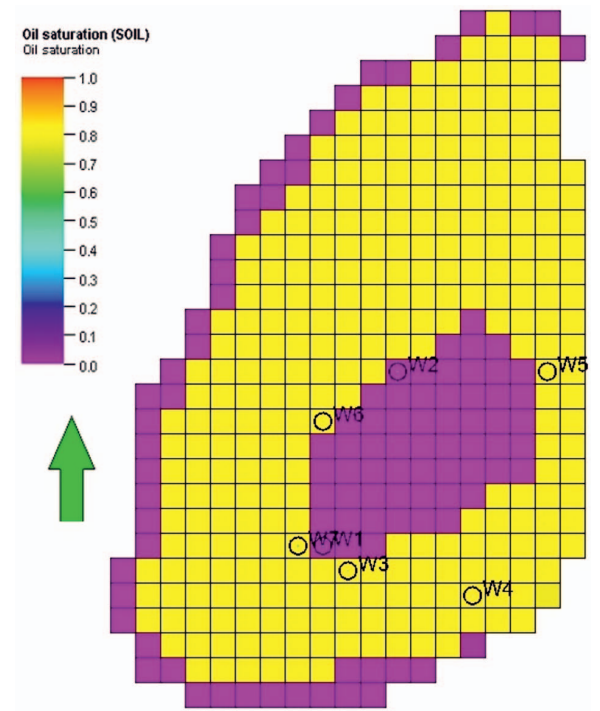

Rys. 11. Optymalna lokalizacja odwiertów 7 odwiertów wydobywczych

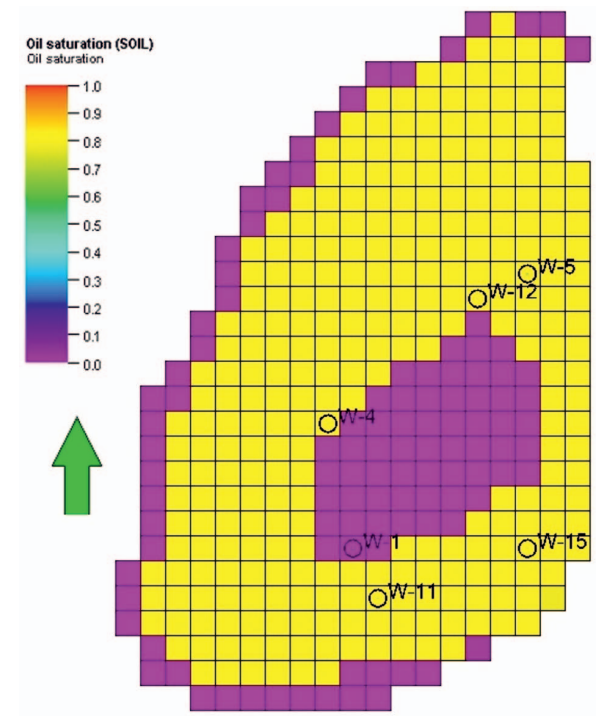

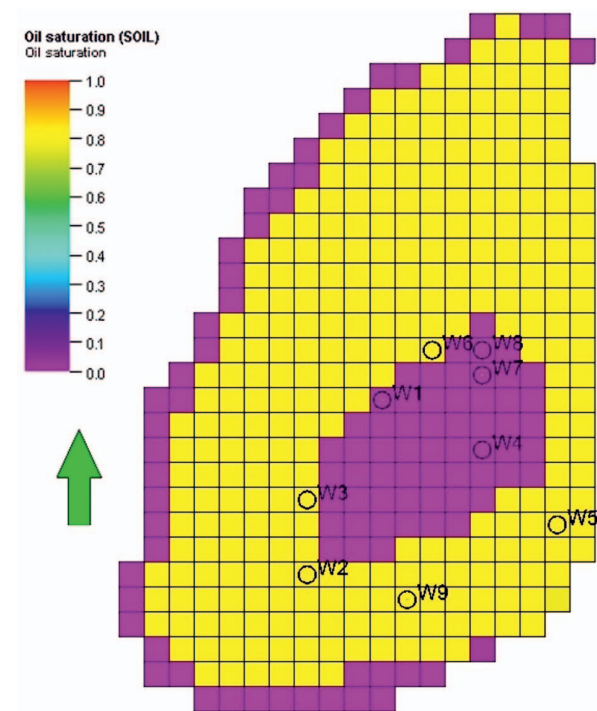

Rys. 12. Optymalna lokalizacja odwiertów 9 odwiertów wydobywczych
Rys. 13. Rzeczywista lokalizacja odwiertów na złożu testowym - PUNQ-S3

\section{Podsumowanie i wnioski}

Celem pracy była próba zastosowania automatycznego algorytmu doboru liczby i lokalizacji odwiertów wydobywczych w celu optymalizacji wydobycia ropy naftowej w zadanym okresie eksploatacji. Zakres pracy obejmował:

- wybór metody optymalizacji dla potrzeb postawionego problemu optymalizacyjnego,

- zbudowanie efektywnego algorytmu genetycznego realizującego proces optymalizacji,

- implementację numeryczną stworzonego algorytmu,

- przeprowadzenie symulacji działania algorytmu w celu znalezienia optymalnej liczby i lokalizacji odwiertów wydobywczych dla wybranego złoża testowego.

W wyniku wykonanych symulacji potwierdzono możliwość zastosowania wybranej heurystyki do optymalizacji liczby i lokalizacji odwiertów przy założonych warunkach ograniczających.
Przeprowadzone analizy symulacyjne pozwalają sformułować następujące wnioski i uwagi:

1. Zastosowana metoda okazała się efektywna dla rozwiązania postawionego problemu optymalizacyjnego. Wykonane testy wykazały zadowalającą zbieżność zbudowanego algorytmu dla różnej liczby odwiertów wydobywczych oraz dostateczną powtarzalność wyników.

2. W każdym z analizowanych wariantów (liczba odwiertów wydobywczych: 5-9) algorytm rozmieszczał odwierty w pobliżu kontaktu ropa-gaz, skutecznie eliminując lokalizacje mające negatywny wpływ na wydobycie, tzn. kontakt ropa-woda oraz brzeg modelu symulacyjnego.

3. Lokalizacja otrzymana dla sześciu odwiertów wykazuje istotne podobieństwo do rzeczywistej lokalizacji odwiertów złoża testowego (rysunki 10 i 13). 
Prosimy cytować jako: Nafta-Gaz 2018, nr 8, s. 598-605, DOI: 10.18668/NG.2018.08.05

Artykuł nadesłano do Redakcji 12.04.2018 r. Zatwierdzono do druku 21.06.2018 r.

Artykuł powstał na podstawie pracy statutowej pt.: Zastosowanie automatycznego algorytmu doboru optymalnej liczby i położenia odwiertów wydobywczych - praca INiG - PIB na zlecenie MNiSW; nr zlecenia: 65/KZ, nr archiwalny: DK-4100-52/17.

\section{Literatura}

[1] Askari Firoozjaee R., Khamehchi E.: A novel approach to assist history matching using artificial intelligence. Chem. Eng. Commun. 2015, vol. 202, nr 4, s. 513-514.

[2] Bakhteeyar H., Maleki A.: Development of two intelligencebased scenarios for prediction of future natural gas consumption. J. Sci. Res. Dev. 2015, vol. 2, nr 1, s. 158-166.

[3] Barker W.J., Cuypers M., Holden L.: Quantifying uncertainty in production forecasts: another look at the PUNQ-S3 problem. SPE J. 2001, vol. 6, nr 4, s. 433-441.

[4] Bouzarkouna Z., Ding D.Y., Auger A.: Partially separated metamodels with evolution strategies for well-placement optimization. SPE J. 2013, vol. 18, nr 6, s. 1003-1011, SPE143292-PA.

[5] Ebrahimi A., Khamehchi E.: A robust model for computing pressure drop in vertical multiphase flow. JNGSE 2015, vol. 26, s. $1306-1316$.

[6] Floris F.J.T., Bush M.D., Cuypers M., Roggero F., Syversveen A.-R.: Methods for quantifying the uncertainty of production forecasts: a comparative study. Pet. Geosci. 2001, vol. 7, s. 87-96.

[7] Goldberg D.E.: Computer Aided Gas Pipeline Operation Using Genetic Algorithms and Rule Learning (Ph.D. dissertation). University of Michigan, Ann Arbor, Michigan, 1983.

[8] Guerreiro J.N.C. et al.: Identification of reservoir heterogeneities using tracer breakthrough profiles and genetic algorithms. SPE 39066. Latin American and Caribbean Petroleum Engineering Conference and Exhibition held in Rio de Janeiro, Brazil, 30.08-3.09.1997.

[9] Güyagüler B., Horne R.N.: Uncertainty assessment of wellplacement optimization. SPE J. 2004, vol. 7, nr 1, s. 24-32, SPE 87663-PA.

[10] Hazlett R.D., Babu D.K.: Optimal well placement in heterogeneous reservoirs via semi-analytic modeling. SPE J. 2005, vol. 10, nr 3, s. 286-296, SPE 84281-PA.

[11] Holland J.H.: Adaptation in Natural and Artificial Systems. University of Michigan Press, Ann Arbor, 1975.

[12] Isebor O.J., Echeverría Ciaurri D., Durlofsky L.: Generalized field-development optimization with derivative-free procedures. SPE J. 2014, vol. 19, nr 5, s. 891-908, SPE-163631-PA.

[13] Keshavarz M., Naderi M.: Drilling rate of penetration prediction and optimization using response surface methodology and bat algorithm. J. Nat. Gas. Sci. Eng. 2016, vol. 31, s. 829-841.

[14] Khamehchi E., Rahimzadeh Kivi I., Akbari M.: A novel approach to sand production prediction using artificial intelligence. PSE 2014, vol. 123, s. 147-154.

[15] Khan K., Sahari A.: A fuzzy c-means bi-sonar-based metaheuristic optimization algorithm. Int. J. Interact. Multimed. Artif. Intell. 2012, vol. 1, nr 7, s. 26-32.

[16] Komarasamy G., Wahi A.: An optimized K-means clustering technique using bat algorithm. Eur. J. Sci. Res. 2012, vol. 84, nr 2, s. 263-273.

[17] Lin J.H., Chou C.W., Yang C.H., Tsai H.L.: A chaotic Levy flight bat algorithm for parameter estimation in nonlinear dynamic biological systems. J. Comput. Inf. Technol. 2012, vol. 2, no. 2, s. $56-63$.

[18] Naderi M., Khamehchi E.: Nonlinear risk optimization approach to water drive gas reservoir production optimization using DOE and artificial intelligence. J. Nat. Gas. Sci. Eng. 2016, vol. 31, s. 575-584.

[19] Onwunalu J.E., Durlofsky L.: A new well-pattern-optimization procedure for large-scale field development. SPE J. 2011, vol. 16, nr 3, s. 594-607, SPE 124364-PA.

[20] Rasouli H., Rashidi F., Karimi B., Khamehchi E.: A surrogate integrated production modeling approach to long-term gas-lift allocation optimization. Chem. Eng. Commun. 2015, vol. 202, nr 5, s. 647-654.

[21] Rwechungura R.W., Dadashpour M., Kleppe J.: Application of Particle Swarm Optimization for Parameter Estimation Integrating Production and Time Lapse Seismic Data. SPE146199-MS, 6-8.09.2011, Aberdeen, UK.

[22] Wang H., Echeverría-Ciaurri D., Cominelli, A.: Optimal well placement under uncertainty using a retrospective optimization framework. SPE J. 2012, vol. 17, nr 1, s. 112-121, SPE 141950-PA.

[23] Yang X.-S.: A New Metaheuristic Bat-Inspired Algorithm. [W:] C. Cruz et al. (eds.): Nature Inspired Cooperative Strategies for Optimization, Studies in Computational Intelligence. Springer, Berlin 2010, vol. 284, s. 65-74.

[24] Yang X.S., Gandomi A.H.: Bat algorithm: a novel approach for global engineering optimization. Eng. Comput. 2012, vol. 29, nr 5, s. 464-483.

[25] Yeten B., Durlofsky L., Aziz K.: Optimization of nonconventional well type, location, and trajectory. SPE J. 2003, vol. 8, nr 3, s. 200-210, SPE 86880-PA.

[26] Zandvliet M., Handels M., Essen G.V., Brouwer R., Jansen J.D.: Adjoint-based well-placement optimization Under production constraints. SPE J. 2008, vol. 13, nr 4, s. 392-399, SPE 105797-PA.

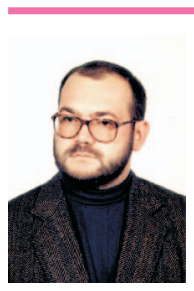

Dr inż. Piotr ŁETKOWSKI

Adiunkt w Zakładzie Symulacji Złóż Węglowodorów i Podziemnych Magazynów Gazu.

Instytut Nafty i Gazu - Państwowy Instytut Badawczy

ul. Lubicz 25 A

31-503 Kraków

E-mail: piotr.letkowski@inig.pl 